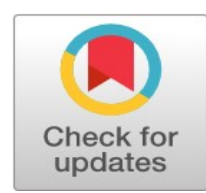

\title{
Influence of individual characteristics and work environment on employee's motivation and performance
}

\author{
Hairul Warizin * \\ School of Economics Sekolah Tinggi Ilmu Ekonomi Indonesia, Surabaya, Indonesia
}

\author{
Keywords \\ Individual characteristics \\ Work environment \\ Employee motivation \\ Performance
}

Received: 29 September 2017

Accepted: 1 October 2017

Published: 9 October 2017

\begin{abstract}
This research is to know the influence of individual characteristics and work environment on employee's motivation, influence of individual characteristics and work environment on performance, influence of employee's motivation on performance, and to know influence of employee's motivation as intervening individual characteristics and work environment on performance. The methodology uses two stages, test of instrument quality and hypothesis testing. The data collection technique used a census because the population was only 76 people. Individual characteristics have a significant influence on employee's motivation and performance, work environment has a significant influence on employee's motivation but has no significant influence on performance. The test results show that the employee's motivation variable mediates the influence of individual characteristics and work environment on performance. This research update on motivation variable as intervening variable between individual characteristics variable, performance variable, research location, and variable relation model. Limitations of this study include the number of samples being only 76 subjectivities. Also, research should be held again in different places with more samples.
\end{abstract}

(C) 2017 The Author(s). Published by TAF Publishing.

\section{INTRODUCTION}

\section{Background}

Management of Human Resources (HR) in companies in the era of the 21st century is getting a big attention. This can't be separated from the emergence of management awareness about the role of $\mathrm{HR}$ as one of the determining factors in achieving company goals. From a macro perspective, the Theory of Economic Growth states that human capital accumulation contributes primarily to macroeconomic growth; while from the micro side, Human Resource Theory considers human capital as the primary resource for sustainable competitive advantage for the company (Lucas, 1998; Oetomo, Satrio, \& Lestariningsih, 2016).

The role of HR is increasingly important when viewed from the supply and demand side of the labor market, where human capital is the level of conformity between demand and supply of labor with the quality and quantity of HR itself.

Companies in the current era of the modern economy are constantly challenged to meet the demand for quality labor, marked by the inability of the labor market to meet those needs (Hamalik, 2007; Luthans \& Fred, 1992; Mohamad Yusof, Munap, Mohd Badrillah, Ab Hamid, \& Md Khir, 2017; Robin, 1990; Silahtaroglu \& Vardarlier, 2016). According to Jain \& Bhatt (2015), Myskowski, Storme, Davila, \& Lubart (2014), Sabella \& Analoui (2015), Tong \& Arvey (2015) some important aspects of the role of HR for the organization or company to further improve the competence of HR management in achieving the goal influence and efficiency of organization. Recognition of the impor-

\footnotetext{
* Corresponding author: Hairul Warizin

${ }^{\dagger}$ Email: hairulwarizin@gmail.com
} 
tance of the role of human capital led to increased research in the field of human resource management, generally about the management of employment within a company. Labor management begins recruitment, selection, placement, and compensation. Further labor must be organized in tasks and responsibilities.

\section{Research Problems}

There are still differences in the results of research between the variables of individual characteristics, work environment, and motivation to performance.

\section{Previous Research}

Some of the results of previous research are used as study materials by researchers to obtain a description of research results and discussion that is devoted to research using variables similar to the research variables. Some of the results of previous research include the following:

1. Liosten \& Ully Tampubolon (2007), The influence of job characteristics and individual characteristics on job satisfaction, commitment and worker atitude toward organizational change at PT. earth tower internusa surabaya.

2. Brahmasari \& Suprayetno (2008), The influence of employee motivation, leadership and organizational culture on employee satisfaction and its impact on company performance (case study on PT Pei Hai International Wiratama Indonesia).

3. Locke, Latham \& Erez (1988), The determinations of goal commitment.

4. Murisha (2011), Influences of work Behavior, work environment and motivation in clove cigarette factories in kudus Indonesia.

5. Moulana (2017), Influence working linkage to performance through variable mediator motivation work (a study on employees of PT Telkom Indonesia.

6. Park (2005), The Influence of organizational culture on job motivation and job satisfaction and performance in the industrial sub-sector.

7. Setiawan (2013), Influences of individual characteristics and work environment on performance at PT.

8. Pujiwati \& Susanty (2017), The influence of individual characteristics and employee motivation on performance.

\section{Research Hypothesis}

Based on the conceptual framework, the hypotheses proposed in this study are:

H1. Individual characteristics have a significant influence on employee's motivation.
H2. Working environment has a significant influence on employee's motivation.

H3. Individual characteristics have a significant influence on performance.

H4. Work environment has a significant influence on performance.

H5. Employee's motivation has a significant influence on performance.

H6. Employee's motivation mediates the influence between individual characteristics on performance.

H7. Employee's motivation mediates the influence of the work environment on performance.

\section{RESEARCH METHODS}

This study uses quantitative methods with the aim of testing the hypotheses (Ferdinand, 2006).

\section{Objectives of Research}

The object of this research is all the employees of PT. Wismatata Eltra Perkasa having address at Popoh Village, Wonoayu Sub district, Sidoarjo Regency with 76 employees consisting of production staff and administrative staff with highest supervisor class. This company is engaged in maintenance and repairing $20 \mathrm{KV}$ Distribution Transformer. Since the population is only 76 people then all populations are included in the research or by using the census method (Sugiyono, 2013).

\section{Technical Testing and Data Analysis}

In this study, testing and data analysis consist of two parts namely testing of variable instrument quality and hypothesis testing.

\section{Testing against instrument variable qualities}

The presence of correlation is reflected in the probability of significance of the correlation test results indicating the value of $<\alpha=0.05$, or in other words, if $r$ arithmetic for each indicator is greater than $r$ table with positive correlation value (Ghozali, 2006). Instrument reliability test is done by calculating the coefficient of Cronbach's alpha. Indicators are said to be reliable if the value of Cronbach's $\alpha>$ 0.6 (Ghozali, 2006).

In addition to analyzing the results of statistical tests, descriptive analysis was also conducted. Descriptive analysis gives an overview of the composition and demographics of research respondents covering the last level of education, part of assignment, position, and years of service. In the de 
scriptive analysis is also given a description of the variables based on existing demographic data. Demographic data are provided in the form of options over several groups of demographic data, so that there may be respondents who do not vote in the demographic data field, but fill in the questionnaires used in the complete indicator.

\section{Hypothesis testing}

Hypothesis testing uses path analysis. Path analysis is an extension of multiple regression analysis to estimate quality relationship between predetermined variables based on theory. Path analysis is used to determine the relationship pattern between three or more variables and can't be used to confirm or reject the hypothesis of imaginary causes (Ghozali, 2006).

\section{RESEARCH RESULT AND DISCUSSION Test Validity Instruments}

Test Instrument Validity. This study uses questionnaires to collect research data, if the correlation value of Pearson ( $r$-count) between two variables that is latent (measured) with indicator variable (measured) with the value of significance (2-tailed) 0.000 at the level of significance (level of significance $/ \alpha$ ) at correlation of 0.05 . The results of the analysis in the above table show that all indicators for the variable Performance are greater than 0.05 so that all indicators are declared invalid or be able to measure all the variables.

TABLE 1 . Test results validity variable individual characteristics (X1)

\begin{tabular}{lccc}
\hline \hline Variables & Indicator & $\boldsymbol{R}$ Count & Conclusion \\
\hline Individual & $\mathrm{X} 1.1$ & 0,499 & Valid \\
Characteristics & $\mathrm{X} 1.2$ & 0.585 & Valid \\
& $\mathrm{X} 1.3$ & 0.673 & Valid \\
Work & $\mathrm{X} 2.1$ & 0.429 & Valid \\
Environment & $\mathrm{X} 2.2$ & 0.819 & Valid \\
& $\mathrm{X} 2.3$ & 0.709 & Valid \\
Employee & $\mathrm{Z} 1$ & 0.510 & Valid \\
Motivation & $\mathrm{Z} 2$ & 0.735 & Valid \\
& $\mathrm{Z} 3$ & 0.735 & Valid \\
Performance & $\mathrm{Y} 1$ & 0.654 & Valid \\
& $\mathrm{Y} 2$ & 0.441 & Valid \\
\hline \hline & $\mathrm{Y} 3$ & 0.601 & Valid \\
\hline Source: 2016 processed data &
\end{tabular}

\section{Test Reliability Instruments}

Reliability questionnaire means the ability of measuring tools to measure consistently. The test is used to mea sure the consistency is Cronbach's coefficient alpha or alpha.
Measurement items are said to be reliable if they have more BESA alpha coefficient $r$ of 0.6 (Moulana, 2017).

TABLE 2 . Reliability test results

\begin{tabular}{lcc}
\hline \hline Variables & Alpha & Reliability \\
\hline Individual Characteristics & 0.717 & Reliable \\
Working Environment of Employees & 0.693 & Reliable \\
Employee Motivation & 0.620 & Reliable \\
Performance & 0.773 & Reliable \\
\hline \hline
\end{tabular}

Source: 2016 processed data

Internal consistency reliability value is shown in the Table above, for alpha coefficient is reliable because it is greater than 0.6. Thus the measurement of items in each of the indicators in the study variables is declared unreliable and can then be used in research.

\section{Description Research (Answer Respondents)}

Description of the results of the study is a description of respondents' answers which is the result of respondents' answers on each research variable. Description of the an swers will be explained based on the frequency and mean calculation results of each variable that has been categorized.

TABLE 3 . Assessment category

\begin{tabular}{ll}
\hline \hline Interval & Category \\
\hline $1-2$ & Low \\
2.1 to 3 & Medium/Enough \\
3.1 to 4 & High \\
From 4.1 to 5 & Very high \\
\hline \hline Source: Though the data in 2016
\end{tabular}

\section{Individual Characteristics (X1)}

Individual Characteristics variable consists of 8 (Eight) questions or statements. Here is a description of the respondents' answers to the variable Characteristics of Individuals.

TABLE 4. Description of responses of respondents on individual characteristics

\begin{tabular}{|c|c|c|c|c|c|c|c|c|c|c|}
\hline \multirow[t]{2}{*}{ No } & \multirow[t]{2}{*}{ Indicator } & \multicolumn{5}{|c|}{ Percentage of Answer Score } & \multirow{2}{*}{ Total } & \multirow[t]{2}{*}{$\%$} & \multirow[t]{2}{*}{ Mean } & \multirow{2}{*}{ Category } \\
\hline & & 1 & 2 & 3 & 4 & 5 & & & & \\
\hline 1 & $\mathrm{X} 1.1$ & 8 & 26 & 18 & 20 & 4 & 76 & 100 & 2.82 & Medium \\
\hline 2 & $\mathrm{X} 1.2$ & 8 & 32 & 12 & 22 & 2 & 76 & 100 & 2.71 & Medium \\
\hline 3 & $\mathrm{X} 1.3$ & 12 & 46 & 6 & 10 & 2 & 76 & 100 & 2.26 & Medium \\
\hline 4 & $\mathrm{X} 1.4$ & 14 & 40 & 16 & 4 & 2 & 76 & 100 & 2.21 & Medium \\
\hline 5 & $\mathrm{X} 1.5$ & 24 & 24 & 14 & 14 & 0 & 76 & 100 & 2.24 & Medium \\
\hline 6 & $\mathrm{X} 1.6$ & 12 & 34 & 24 & 6 & 0 & 76 & 100 & 2.32 & Medium \\
\hline 7 & X1.7 & 26 & 24 & 21 & 4 & 0 & 76 & 100 & 2.06 & Medium \\
\hline \multirow[t]{2}{*}{8} & X1.8 & 14 & 28 & 22 & 12 & 0 & 76 & 100 & 2.47 & Medium \\
\hline & Average & & & & & & & & 2.37 & Medium \\
\hline
\end{tabular}

Source: 2016 processed data 


\section{Working Environment (X2)}

Variable working environment consists of 8 (Eight) questions or statements. The following is a description of the respondents' answers to the work environment variable of the employee.

TABLE 5 . Description of respondents' responses on working environment employees

\begin{tabular}{|c|c|c|c|c|c|c|c|c|c|c|}
\hline \multirow[t]{2}{*}{ No } & \multirow[t]{2}{*}{ Indicator } & \multicolumn{5}{|c|}{ Percentage of Answer Score } & \multirow[t]{2}{*}{ Total } & \multirow[t]{2}{*}{$\%$} & \multirow[t]{2}{*}{ Mean } & \multirow[t]{2}{*}{ Category } \\
\hline & & 1 & 2 & 3 & 4 & 5 & & & & \\
\hline 1 & $\mathrm{X} 2.1$ & 18 & 38 & 12 & 8 & 0 & 76 & 100 & 2.13 & Medium \\
\hline 2 & $\mathrm{X} 2.2$ & 18 & 38 & 12 & 8 & 0 & 76 & 100 & 2.13 & Medium \\
\hline 3 & $\mathrm{X} 2.3$ & 17 & 32 & 14 & 8 & 5 & 76 & 100 & 2.63 & Medium \\
\hline 4 & $\mathrm{X} 2.4$ & 18 & 22 & 24 & 12 & 0 & 76 & 100 & 2.39 & Medium \\
\hline 5 & $\mathrm{X} 2.5$ & 18 & 34 & 12 & 8 & 4 & 76 & 100 & 2.29 & Medium \\
\hline 6 & $\mathrm{X} 2.6$ & 18 & 36 & 14 & 8 & 0 & 76 & 100 & 2.16 & Medium \\
\hline 7 & $\mathrm{X} 2.7$ & 12 & 30 & 20 & 14 & 0 & 76 & 100 & 2.47 & Medium \\
\hline \multirow[t]{2}{*}{8} & $\mathrm{X} 2.8$ & 24 & 20 & 20 & 12 & 0 & 76 & 100 & 2.26 & Medium \\
\hline & Average & & & & & & & & 2.31 & Medium \\
\hline
\end{tabular}

\section{Employee's Motivation (Z)}

Variable employee's motivation consists of 7 (Seven) questions or statements. Here is a description of respondents' answers on employee's motivation variable.

TABLE 6 . Description of respondents' responses on employee's motivation

\begin{tabular}{|c|c|c|c|c|c|c|c|c|c|c|}
\hline \multirow[t]{2}{*}{ No } & \multirow[t]{2}{*}{ Indicator } & \multicolumn{5}{|c|}{ Percentage of Answer Score } & \multirow[t]{2}{*}{ Total } & \multirow[t]{2}{*}{$\%$} & \multirow[t]{2}{*}{ Mean } & \multirow[t]{2}{*}{ Category } \\
\hline & & 1 & 2 & 3 & 4 & 5 & & & & \\
\hline 1 & $\mathrm{Z} 1$ & 8 & 48 & 16 & 2 & 2 & 76 & 100 & 2.24 & Medium \\
\hline 2 & $\mathrm{Z} 2$ & 24 & 16 & 24 & 10 & 2 & 76 & 100 & 2.34 & Medium \\
\hline 3 & $\mathrm{Z3}$ & 22 & 26 & 14 & 12 & 2 & 76 & 100 & 2.29 & Medium \\
\hline 4 & $\mathrm{Z} 4$ & 14 & 32 & 16 & 14 & 0 & 76 & 100 & 2.39 & Medium \\
\hline 5 & Z5 & 14 & 36 & 12 & 12 & 2 & 76 & 100 & 2.37 & Medium \\
\hline 6 & Z6 & 6 & 26 & 16 & 24 & 0 & 76 & 100 & 2.92 & Medium \\
\hline \multirow[t]{2}{*}{7} & $\mathrm{Z7}$ & 8 & 28 & 18 & 10 & 12 & 76 & 100 & 2.87 & Medium \\
\hline & Average & & & & & & & & 2.49 & Medium \\
\hline
\end{tabular}

Source: 2016 processed data

\section{Performance (Y)}

Performance variables consist of twelve (12) questions or statements. The following is a description of the respondents' answers on performance variables.

TABLE 7 . Description of respondents' responses on employee's motivation

\begin{tabular}{|c|c|c|c|c|c|c|c|c|c|c|}
\hline \multirow[t]{2}{*}{ No } & \multirow[t]{2}{*}{ Indicator } & \multicolumn{5}{|c|}{ Percentage of Answer Score } & \multirow[t]{2}{*}{ Total } & \multirow[t]{2}{*}{$\%$} & \multirow[t]{2}{*}{ Mean } & \multirow[t]{2}{*}{ Category } \\
\hline & & 1 & 2 & 3 & 4 & 5 & & & & \\
\hline 1 & Y1 & 22 & 40 & 8 & 6 & 0 & 76 & 100 & 1.87 & Medium \\
\hline 2 & Y2 & 10 & 42 & 18 & 4 & 2 & 76 & 100 & 2.23 & Medium \\
\hline 3 & Y3 & 18 & 34 & 16 & 6 & 2 & 76 & 100 & 2.21 & Medium \\
\hline 4 & $\mathrm{Y} 4$ & 20 & 38 & 12 & 2 & 4 & 76 & 100 & 2.11 & Medium \\
\hline 5 & Y5 & 16 & 30 & 22 & 6 & 2 & 76 & 100 & 2.23 & Medium \\
\hline 6 & Y6 & 12 & 28 & 14 & 16 & 6 & 76 & 100 & 2.68 & Medium \\
\hline 7 & Y7 & 6 & 40 & 10 & 8 & 12 & 76 & 100 & 2.74 & Medium \\
\hline 8 & Y8 & 6 & 44 & 22 & 4 & 0 & 76 & 100 & 2.37 & Medium \\
\hline 9 & Y9 & 14 & 42 & 10 & 10 & 0 & 76 & 100 & 2.21 & Medium \\
\hline 10 & Y10 & 14 & 32 & 12 & 12 & 6 & 76 & 100 & 2.53 & Medium \\
\hline 11 & Y11 & 16 & 32 & 6 & 20 & 2 & 76 & 100 & 2.47 & Medium \\
\hline \multirow[t]{2}{*}{12} & $\mathrm{Y} 12$ & 14 & 26 & 16 & 14 & 6 & 76 & 100 & 2.63 & Medium \\
\hline & The average & & & & & & & & 2.38 & Medium \\
\hline
\end{tabular}

\section{Hypothesis testing}

This study formulates 7 hypotheses composed of 2 regression equations as follows:

$W M=\alpha+\beta 1 I C+\beta 2 L K+e$

$P=\alpha+\beta 3 I C+\beta 4 I C+\beta 5 W M+e$

Where:

$W M=$ Employee's motivation

$I C=$ Individual Characteristics

$W E=$ Work Environment

$P=$ Performance

$\beta 1-5=$ Regression coefficient

$e=$ residual value

The test is done by 2 times multiple regression test, which is test for equation 1 and equation 2. Equation 1 is used to answer hypothesis 1 and 2. Equation 2 is used to answer hypothesis 3, hypothesis 4 , and hypothesis 5 , hypothesis 6 and hypothesis 7 are answered by interpreting the direct and indirect power of influence resulting from equation 1 and equation 2 . The following is the result of equation 1.

TABLE 8. Statistical test results equation 1 model summary

\begin{tabular}{lllll}
\hline \hline Model & $\boldsymbol{R}$ & $\boldsymbol{R}$ Square & Adjusted $\boldsymbol{R}$ Square & Std. Error of the $\boldsymbol{R}$ estimate \\
\hline 1 & .765 & .585 & .574 & .45086 \\
\hline \hline a. Predictors: (Constant), Environment, Character &
\end{tabular}

a. Predictors: (Constant), Environment, Character

\begin{tabular}{llllll} 
ANOVA $^{b}$ & \multicolumn{1}{l}{} \\
\hline \hline Model & Sum of Squares & $\boldsymbol{D} \boldsymbol{f}$ & Mean Square & $\boldsymbol{F}$ & Sig. \\
\hline 1 Regression & 20.951 & 2 & 10.475 & 51.534 & .000 \\
Residual & 14.839 & 73 & .203 & & \\
Total & 35.789 & 75 & & & \\
\hline
\end{tabular}




\begin{tabular}{lccccc} 
Coefficients $^{a}$ & & & \\
\hline \multirow{2}{*}{ Model } & \multicolumn{2}{l}{ Unstandardized Coefficients } & Standardized Coefficients & $\boldsymbol{T}$ & Sig. \\
& $\boldsymbol{B}$ & Std. Error & & Beta & \\
\hline 1 (Constant) & .442 & .177 & & 2.494 & .015 \\
Character & .290 & .079 & .288 & 3.671 & .000 \\
Environment & .567 & .070 & .634 & 8.083 & .000 \\
\hline \hline
\end{tabular}

a. Dependent variable: Employee's motivation

Test results consist of 3 test results and can be implemented as follows:

1. Table Model Summary shows the ability of independent variables (individual characteristics and work environment) in explaining the dependent variable in the equation test 1 (Employee's motivation). Rated $R$-Square $=0$, 585 regarded as the coefficient of determination. This means that individual characteristics and environmental variables in the models tested working with equation are one able to explain the motivation variable work by $58.5 \%$. While 41.5\% (100\% - 58.5\%) determinant (determinant) motivation to work is another variable outside the model examined/tested by equation 1 .

2. ANOVA table is the result of $F$ test. $F$ test result is useful to know whether the model tested is fit/good or not. The model is said to be fit if the $F$ test results showed prob. sig- nificant value $<0.05 . F$ test results show 0.000 value. This figure is well below 0.05 , so the model tested with equation 1 is good/fit.

3. Table of Coefficient shows the results of $t$-test. The $t$-test to analyze the influence of each independent variable that is characteristics of the individual and the work environment on the dependent variable (Employee's motivation). The test results are used to answer the hypothesis 1 and hypothesis 2. Based on these test results, it appears that the individual characteristics and work environment significantly influence the employee's motivation. This is evident:

a. Value prob. significant influence of individual characteristics on employee's motivation of $0.000(<0.05)$.

b. Value prob. significant work environment influence on employee's motivation of $0.000(<0.05)$.

The result of test of equation 2 is as follows:

TABLE 9. Statistical test results equation 2 model summary

\begin{tabular}{lllll}
\hline \hline Model & $\boldsymbol{R}$ & $\boldsymbol{R}$ Square & Adjusted $\boldsymbol{R}$ Square & Std. Error of the $\boldsymbol{R}$ estimate \\
\hline 1 & .707 & .500 & .479 & .45296 \\
\hline \hline a. Predictors: (Constant), Motivation, Characteristics, Environment
\end{tabular}

\begin{tabular}{llllll} 
ANOVA $^{b}$ & \multicolumn{1}{l}{} \\
\hline \hline Model & Sum of Squares & $\boldsymbol{D f}$ & Mean Square & $\boldsymbol{F}$ & Sig. \\
\hline 1 Regression & 14.754 & 3 & 4.918 & 23.970 & .000 \\
Residual & 14.772 & 72 & .205 & & \\
Total & 29.526 & 75 & & & \\
\hline \hline \\
a. Predictors: (Constant), Motivation, Characteristics, Environment \\
b. Dependent variable: Performance
\end{tabular}

\begin{tabular}{lccccc}
\multicolumn{1}{l}{ Coefficients $^{a}$} \\
\hline \hline Model & \multicolumn{1}{l}{ Unstandardized Coefficients } & $\begin{array}{c}\text { Standardized Coefficients } \\
\text { Beta }\end{array}$ & $\boldsymbol{T}$ & Sig. \\
\cline { 2 - 3 } & $\boldsymbol{B}$ & Std. Error & & & \\
\hline 1 (Constant) & .545 & .186 & .538 & 5.697 & .005 \\
Character & .493 & .087 & -.154 & -1.286 & .2003 \\
Environment & -.125 & .097 & .362 & 2.800 & .007 \\
Motivation & .329 & .118 & & &
\end{tabular}

a. Dependent variable: Performance 
The results of testing of equation 2 can be interpreted as follows:

1. Table Summary Model shows the independent ability of variable (characteristic, environment, and motivation) in explaining dependent variable in testing equation 2 (performance). Rated $R$-Square $=0.500$

2. ANOVA table is the result of $F$ test. The model is said to be fit if the result of $F$ test shows the value of pro. significant $<0.05$. $F$ test results show 0.000 value. This figure is well below 0.05 , so the model tested is fit.

3. Coefficient table shows t-test results. $T$-test aims to analyze the influence of each independent variable that is individual characteristics, work environment, and employee's motivation on dependent variable (performance). The results of this test are used to answer hypothesis 3, 4, and 5 respectively. Based on the test results, it appears that:

a. Individual characteristics have a significant influence on performance. This is evident from the prob. significant value of the influence of individual characteristics on performance of employees by $0.000(<0.05)$.

b. Work environment has no significant influence on performance. This is evident from the value prob. sig work environment influence on performance by $0.203(>0.05)$.

c. Motivation of work has a significant influence on performance. This is evident from the value prob. significant influence of employee's motivation on performance by $0.007(<0.05)$.

Based on these tests, the description of the results of the research model and its influences can be illustrated as shown on the following page:

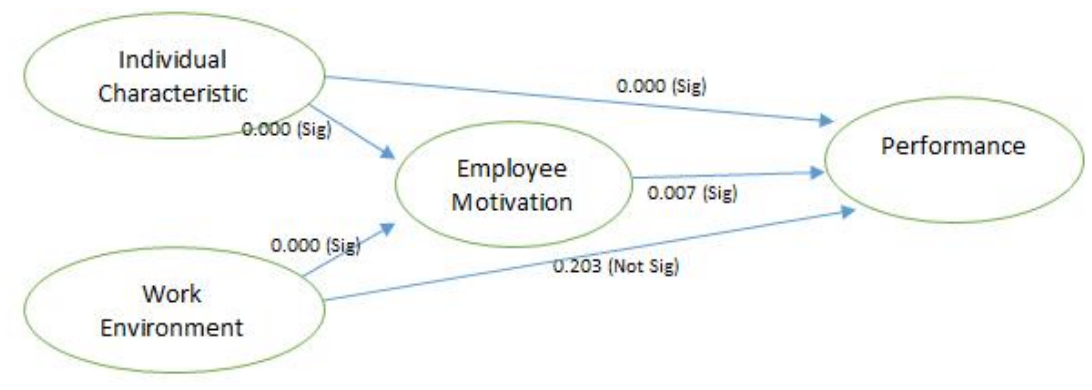

FIGURE 1. Model

Based on the test results, we found evidence that individual characteristics and work environment have a significant influence on employee's motivation and also individual characteristics significantly influence performance while the work environment has no significant influence on performance.

Hypotheses 6 and 7 are determined by the combined test results of equation 1 and equation 2 where

1. Hypothesis 6 is formulated to test the role of employee's motivation mediation in the influence of individual characteristics on performance. This hypothesis is evident if:

a. Individual characteristics have a significant influence on performance.

b. Individual characteristics have a significant influence on employee's motivation.

c. Employee's motivation has a significant influence on performance. d. The magnitude of indirect influence is greater than the direct influence.

Based on these criteria, hypothesis 6 is proven, so that employee's motivation can mediate the influence of individual characteristics on performance.

2. Hypothesis 7 is formulated to test the role of mediation of employee's motivation in the influence of work environment on performance. This hypothesis is evident if:

a. Work environment has a significant influence on performance.

b. Work environment has a significant influence on employee's motivation.

c. Employee's motivation has a significant influence on performance.

d. The magnitude of indirect influence is greater than the direct influence.

Based on the criteria, hypothesis 7 is proven, so that the employee's motivation mediates the influence of work environment on performance. 
TABLE 10 . Summary of hypothesis testing results

\begin{tabular}{lllll}
\hline \hline Hypothesis & Influence of Variables & $\boldsymbol{t}$-count & Prob. Significant & Information \\
\hline H1 & Characteristic $\rightarrow$ Motivation & 3.671 & 0.000 & Significant \\
H2 & Work Environment $\rightarrow$ Motivation & 8.083 & 0.000 & Significant \\
H3 & Characteristic $\rightarrow$ Performance & 5.697 & 0.000 & Significant \\
H4 & Work Environment $\rightarrow$ Performance & -1.286 & 0.203 & Not Significant \\
H5 & Motivation $\rightarrow$ Performant & 2.800 & 0.007 & Significant \\
H6 & Characteristic $\rightarrow$ Motivation Performance & - & 0.000 & Mediating \\
& & & 0.007 & \\
H7 & Work Environment $\rightarrow$ Motivation Performance & - & 0.000 & \\
& & & 0.000 & \\
& & & 0.203 & \\
\hline \hline
\end{tabular}

\section{Description Relationship Between Variables}

Of the relationship between variables will be clear variables that are proposed in these hypotheses except variables have a significant influence on performance and work environment.

\section{Influence of individual characteristics on employee's motivation}

Test results obtained $t$-count value of 3.671 with prob. significant $0.000(<\alpha=0.05)$. Based on these results, there is a significant influence of individual characteristics on employee's motivation.

This means that the number one hypothesis in this study is proven. The results of this study support previous research conducted by (Pujiwati \& Susanty, 2017).

\section{Influence of employee's motivation on environment workplace}

Test results obtained t-count value of 8.083 with prob. significant $0.000(<\alpha=0.05)$. Based on these results, there is a significant influence of work environment on employee's motivation.

This means that the second hypothesis in the study is proven. These results support the previous research conducted by (Setiawan, 2013; Moulana, 2017).

\section{Influence of individual characteristics on perfor- mance}

Test results obtained $t$-count value of 5.697 with prob. significant $0.000(<\alpha=0.05)$. Based on these results, there is a significant influence of individual characteristics on performance.

This means that the third hypothesis in this study is proven. These results support previous research con- ducted by (Pujiwati \& Susanty, 2017) but contrary to research conducted by (Setiawan, 2013).

\section{Influence of work environment on performance}

Test results obtained $t$-count value of -1.286 with prob. significant $0.203(>\alpha=0.05)$. Based on these results, the work environment has no significant influence on performance. This means that the fourth hypothesis in this study is not proven. These results contradict with the results of previous studies conducted by (Moulana, 2017; Murisha, 2011; Pujiwati \& Susanty, 2017).

\section{Influence of employee's motivation on performance}

Test results obtained $t$-count value of 2800 with prob. significant $0.007(<\alpha=0.05)$. Based on these results, there is a significant influence of employee's motivation on performance.

This means that the number five hypothesis in this study is proven. These results support the results of previous studies conducted by (Moulana, 2017; Murisha, 2011; Pujiwati \& Susanty, 2017).

\section{Employee's motivation mediates intervening on in- dividual characteristics of performance}

Based on the test results, employee's motivation mediates influence of individual characteristics on performance because it meets all the requirements namely (a) Individual characteristics significantly influence performance with prob. significant $0.000(<\alpha=0.05)$. (b) Individual characteristics have a significant influence on employee's motivation with prob. score. significant $0.000(<\alpha=0.05)$. (c) Employee's motivation has a significant influence on performance with prob. score. significant $0.007(<\alpha=0.05)$. 
(d) The magnitude of indirect influence is greater than the direct influence. This means the number six hypothesis in this study is proven.

\section{Employee's motivation mediates intervening in the} Work environment on performance

Based on the test results, employee's motivation mediates the influence of work environment on the performance of employees because it meets the two requirements $b$ and $c$ that is (b) Work environment has a significant influence on employee's motivation with prob. significant $0.000(<\alpha=$ 0.05). (c) Employee's motivation has a significant influence on performance with prob. score. significant $0.000(<\alpha$ $=0.05$ ). This means that the number seven hypothesis in this study is proven. These results are consistent with the results of the study (Moulana, 2017).

\section{CONCLUSION AND RECOMMENDATIONS}

From the background of the problem, the formulation of the problem, the purpose of research, hypothesis, hypothesis proof, and discussion, it can be concluded and suggestions as follows:

\section{Conclusion}

Individual characteristics have a significant influence on employee's motivation and performance. Work environment has a significant influence on employee's motivation but has no significant influence on performance directly. Employee's motivation mediates the influence of individual characteristics and the work environment on performance.

\begin{abstract}
Suggestions
For future researchers, it is hoped that the results of this study can be useful for use as a reference for similar research with the addition of variables and indicators. The small sample in this research makes result of research very subjective. So they need to conduct further research by using more samples.
\end{abstract}

\section{REFERENCES}

Brahmasari, I.A., \& Suprayetno, A. 2008. The influence of work motivation, leadership and organizational culture on em- ployee satisfaction and its impact on corporate performance (Case study on PT. pei hai international Wiratama Indone- sia). Management \& Entrepreneurship Juornal, 10: 124-135.

Ferdinand, A. 2006. Metode penelitian manajemen. Semarang, ID: Badan Penerbit Universitas Diponegoro.

Ghozali, I. 2006. Aplikasi analisis multivariate dengan program SPSS. Semarang, ID: Badan Penerbit Universitas Dipone goro.

Jain, N., \& Bhatt, P. 2015. Employment preferences of job applicants: Unfolding employer branding determinants. Journal of Management Development, 34(6): 634-652. D0I: 10.1108/jmd-09-2013-0106

Lucas, R.E. 1998. On the mechanics of economic development. Econometric Society Monographs, 29: 61-70.

Luthans, N.A., \& Fred, C. 1992. Organizational behavior. Singapore, SG: McGrow Hill Book Company.

Liosten, R.R., \& Ully, T. 2007. The influence of job characteristics and individual characteristics on job satisfaction commitment and worker atitude toward organizational change at PT, earth tower internusa Surabaya. Unpub- lished doctoral dissertion, University Lampung, Bandung, ID.

Locke, E.A., Latham, G.P., \& Erez, M. 1988. The determinants of goal commitment. Academy of Management Review, 13(1): 23-39.

Hamalik, 0.2007. Manajemen pelatihan ketenagakerjaan pendekatan terpadu: Pengembangan sumber daya manu- $\quad$ sia. Jakarta, ID: Bumi Aksara.

Moulana, F. 2017. Melalui variabel mediator motivasi kerja (Studi pada karyawan PT). Telkom Indonesia Tbk Witel Jatim Selatan, 44(1): 178-185.

Murisha, G. 2011. Influences of work behavior, work environment and motivation inclove cigarette factories in Kudus, In- donesia. Academic Research International, 1(3): 303-314.

Myskowski, N., Storme, M., Davila, A., \& Lubart, T. 2015. Managerial creative problem solving and the big five personality traits: Distinguishing divergent and convergent thinking. Journal of Management Development, 34(6): 674-684.

DOI: $10.1108 / j m d-12-2013-0160$ 
Mohamad Yusof, H.S., Munap, R. Mohd Badrillah, R.I., Ab Hamid, N.R., \& Md Khir, R. 2017. The relationship between organi- $\quad$ zational culture and employee motivation as moderated by work attitude. Journal of Administrative \& Business Studies,

3(1): 21-25. DOI: $10.20474 /$ jabs-3.1.3

Oetomo, H.W., Satrio, B., \& Lestariningsih, M. 2016. The Leadership style as moderating, influence of compensation, Organi- $\quad$ zational Citizenship Behaviour (OCB), and stress towards intention to quit. International Journal of Business \& Eco- nomic Affairs, 1(1): 6-12. DOI: 10.24088/ijbea-2016-11002

Pujiwati, A., \& Susanty, E. 2017. Analisis faktor-faktor stressor terhadap stres kerja dan kinerja karyawan kementerian keuangan. Jurnal Manajemen, 21(1): 46-52.

Park, K. 2005. The influence of organizational culture on job motivation and job satisfaction and performance in the industrial sub-sector. Unpublished doctoral dessertion, University of Malaya, Kuala Lumpur, MA.

Robin, S.P. 1990. Organization theory. New York, NY: Prentice Hall Inc.

Sabella, A.R., \& Analoui, F. 2015. Managerial training and development in telecommunication organizations in Palestine.

Journal of Management Development, 34(6): 685-703. D0I: 10.1108/jmd-08-2014-0083

Setiawan, J. 2013. Influences of individual characteristics and work environment on performance at PT, awetama bina reksa.

Jurnal Akmenbis, 2(1): 23-26.

Silahtaroglu, G., \& Vardarlier, P. 2016. Leaders impact on organizational behavior: A text mining study on universities in

Turkey. International Journal of Business \& Administrative Studies, 2(2): 52-56. D0I: 10.20469/ijbas.2.10005-2 Sugiyono, G. 2013. Metode penelitian kuantitatif, kualitatif, dan R\&D. Bandung, ID: CV Alfabeta.

Tong, Y.K., \& Arvey, R.D. 2015. Managing complexity via the competing values framework. Journal ofManagement Devel- opment, 34(6): 653-673. DOI: 10.1108/jmd-04-2014-0029 